\title{
Bioenergy Policy: The Biodiesel Sustainability Dilemma in Indonesia
}

\author{
Arya H. Dharmawan ${ }^{1 *}$, Akhmad Fauzi², Eka I.K. Putri², Pablo Pacheco ${ }^{3}$, Ahmad Dermawan ${ }^{3}$, Nuva Nuva ${ }^{2}$, Rizka \\ Amalia $^{4}$, Diyane A. Sudaryanti ${ }^{2}$ \\ ${ }^{1}$ Department of Communication and Community Development Sciences, Bogor Agricultural University, Bogor 16680, \\ Indonesia \\ ${ }^{2}$ Department of Resource and Environmental Economics, Bogor Agricultural University, Bogor 16680 Indonesia \\ ${ }^{3}$ Forests and Governance Program, Centre for International Forestry Research (CIFOR), Bogor 16115, Indonesia \\ ${ }^{4}$ Center for Agricultural and Rural Development Studies, Bogor Agricultural University, Bogor 16143, Indonesia
}

Corresponding Author Email: aryahadidharmawan14@gmail.com

https://doi.org/10.18280/ijsdp.150414

Received: 22 April 2019

Accepted: 15 February 2020

\section{Keywords:}

energy policy, Indonesia, palm oil-based

biodiesel, sustainability problems

\begin{abstract}
Palm oil-based biodiesel in Indonesia is facing critical issue with regard to its sustainability status in both upstream and downstream sides. International market of palm oil keeps questioning this sustainability standard of Indonesia oil palm. Three interrelated dimensions of sustainability should be fulfilled only if a product to gain growing market acceptance internationally, i.e. economically profitable, ecologically sound and socially acceptable. To determine the sustainability of Indonesia's palm oil-based biodiesel, this paper pays attention in particular to measuring sustainability status of biodiesel in the upstream to downstream side along its supply chain. The analysis of the sustainability of palm oil-based biodiesel in Indonesia is done thoroughly all related activities on the upstream (agricultural-cultivation activities) up to the downstream (manufacturing activities) side. A rap-bioenergy approach, which included the use of MDS (multidimensional scaling) analyses is applied in the analysis. The results of these analyses show that palm oil-based biodiesel in Indonesia is facing serious sustainability status. Among other three parameters, ecological aspect/parameter is a very serious one. This is especially the case for cultivation activities. This paper concludes that if Indonesia desires international markets to accept the existence of palm oil-based biodiesel, then improvements in ecological aspect should be priority.
\end{abstract}

\section{INTRODUCTION}

Economic and population growth have led to increasing needs for both fossil fuel-based and non-fossil fuel-based energy [1-5]. However, the availability of fossil fuels continues to fall, bringing long-term consequences to the energy crisis issue [6]. Currently, global attention is focused on the development of new and renewable energy sources as alternatives to substitute dwindling fossil fuels [7, 8]. The development of new and renewable energy is driven by a motivation to reduce carbon emissions from the burning of fossil fuels; particularly their implications for increasing the greenhouse effect and exacerbating climate change, as well as by the motivation to achieve clean energy status, especially in the transport and industry sectors [9]. One type of renewable energy is bioenergy originating from biomass $[10,11]$. The development and utilization of biomass-based biodiesel will provide benefits to the government and society, such as reducing dependence and import of fossil fuels, increasing the economy of the community (smallholders), and increasing employment opportunities $[12,13]$. The mandate in the development and the use of biofuels in various countries also continues to increase, especially to meet domestic needs [14]. Many parties believe that biofuels offer technological solutions that lead to a 'win-win solution' for the environment and the economy [15].
In Indonesia, biofuel development uses a number of raw materials with potential widespread availability from the agriculture sector. Biofuel development has secured legitimacy through Law No. 30/2007 on Energy, and various lower-level legislation. Law No. 30/2007 underlines a commitment to the diversification, conservation, and intensification of energy sources. Sustainability is an essential principle in the national energy policy, where biofuels are a focus of the policy to transition from fossil to non-fossil fuel energy.

One major biofuel in Indonesia is biodiesel with palm oil constituting the predominant raw material. Indonesia is the world's largest producer of palm oil with production increasing year to year (see Figure 1), and has massive potential to encourage bioenergy (biodiesel) development into the future. Palm oil raw material potential is plentiful in Indonesia, with 11.9 million ha of oil palm estates and crude palm oil (CPO) production averaging approximately 43.24 million tons in 2016. Up to 68 percent of Indonesia's palm oil production is aimed at exports in the form of crude, refined and oleo exports [16]. Around 17 percent of total palm oil production is used domestically for local food needs, while five percent is allocated for biodiesel production to supply domestic and overseas markets [17].

Oil palm is also recognized as the estate crop that can produce the largest volumes of vegetable oil compared to other 
crops, so will be more efficient and profitable when used as a raw material for biodiesel [18-20]. Consequently, in the long term, palm oil-based biodiesel will become the focus of renewable energy development policy in Indonesia.

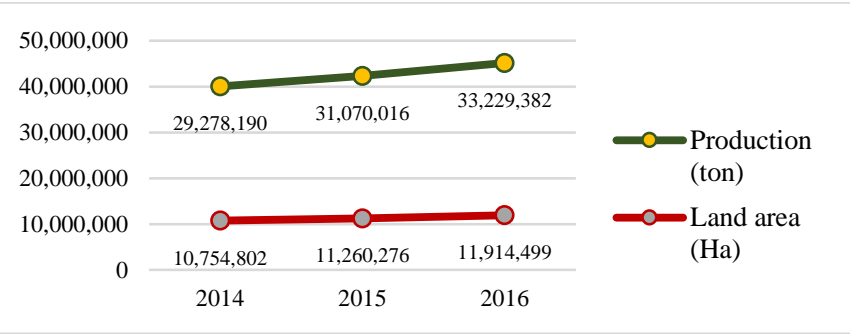

Source: Indonesian Central Statistics Agency, 2016

Figure 1. Indonesia's oil palm planted area and annual palm oil production 2014-2016

\section{PROBLEM STATEMENT}

In 2014, Law No. 30/2007 on Energy was elaborated into a policy on the development of an energy mix and new and renewable energy through Government Regulation (PP) No. $79 / 2014$ on the National Energy Strategy. National energy policy direction ensures an optimum energy mix, with renewables targeted to contribute up to 23 percent of the energy mix by 2025 , and biofuels making up 4.7 percent. The target for 2050 is for bioenergy to contribute 31 percent of the energy mix. These are optimistic targets that hope to be achieved over various constraints, such as issues of land for feedstock, biodiesel prices being higher than those for fossil fuels, dependence on imported technologies and equipment, and low market demand for biodiesel, particularly in sectors with no government intervention [21].

There is a general assumption that biodiesel or bioenergy already fall in line with sustainability principles [22] as they are sourced from the agriculture sector. In reality, biodiesels produced using agriculture product raw materials face various environmental issues, particularly those associated with the expansion of estate crops into conservation and forestry estates [23-26]. This indirectly shows that energy policies encouraging biodiesel do not necessarily meet sustainability principles [27]. Biodiesel development and use has on-ground risks relating not only to environmental issues, but to natural resource and sociocultural issues as well. In this regard, one environmental issue that remains problematic with palm oilbased biodiesel is hazardous spent bleaching earth (SBE) [28], [29]. In regard to natural resource issues, palm oil-based biodiesel development is closely tied to the problem of plantation expansion into protected areas, which risks biodiversity loss as well as hydrological disruption [30, 31]. In sociocultural terms, one potential consequence of oil palm estate expansion being driven by biodiesel production growth is the marginalization of indigenous communities, as has happened in Jambi and East Kalimantan provinces [32, 33].

Biodiesel in Indonesia is facing political economy issues in global markets. Due to an inability to properly account for legality traceability, biodiesel from Indonesia is obstructed by high import tariff policies, which results in an uncompetitive product [34]. The banning policy imposed on palm oil-based biodiesel companies in Indonesia has caused installed capacity to be far from optimum in biodiesel plants; a 70-percent production gap has caused the majority of biodiesel plants in
Indonesia to experience idle capacity (operating at only 30 percent of full production capacity).

Energy policy towards palm oil-based biodiesel production is directed at achieving sustainability through efforts to resolve the various issues above. Sustainability can be achieved, in part, through strict certification processes at the plantation and production plant levels to ensure biodiesel is declared safe and aligned to environmental preservation principles at every stage of the value chain. This paper discusses two important questions that relate to biodiesel production sustainability issues in Indonesia along the entire upstream to downstream value chain [35-37]. These are:

a. To what extent is biodiesel in Indonesia genuinely sustainable in support energy transition?

b. What policies should be formulated to resolve palm oilbased biodiesel sustainability issues in Indonesia?

\section{METHODOLOGY}

This research used primary and secondary data, where surveys and in-depth interviews were conducted to gather primary data at the smallholder level and from other related stakeholders, namely biodiesel business practitioners (3 companies) and Indonesian palm oil company associations. Secondary data was obtained from scientific publications, government reports, and palm oil biodiesel company reports. At the smallholder level, interviews were held in Pelalawan District in Riau Province, and Asahan District in North Sumatra Province. Both locations were selected purposively as they constitute the two (2) provinces with the largest areas of oil palm estates, and have palm oil-based biodiesel plants with combined production in 2016 amounting to 40 percent of national biodiesel production capacity.

Riau Province and North Sumatra Province are two (2) regions in Indonesia that have the largest oil palm plantations and also have biodiesel industries sourced from oil palm. Based on data from the Directorate General of Plantation, Sumatra Island has a total area of oil palm plantations amounting to 67 percent of the total oil palm plantations in Indonesia. The largest area of oil palm plantations in Riau Province is 2,400,886 ha and North Sumatra Province ranks second with a land area of $1,427,021$ ha in 2015 , with total production in the two regions reaching 13.252,981 tons or more than 42 percent of National palm oil production [38]. In addition, in the two provinces there are also palm oil-based biodiesel factories with total production in 2016 reaching $4,716,091 \mathrm{kl}$ or 40 percent of National production [39].

This palm oil-based biodiesel sustainability study used qualitative and quantitative descriptive approaches, as well a rap-bioenergy approach; a modification of the rap-fish technique. The sustainability results will also be strengthened using smallholders' perspectives on the impact of oil palm plantation. Basically, sustainable bioenergy systems are closely tied to social, economic and environmental contexts, and rely on support from many stakeholders with different perspectives [40]. In general, a survey and non-survey approaches was conducted to gather data for this study. Thus, to conduct sustainability assessment, we organize non-survey (in depth interview to key persons on each supply chain actors using purposive sampling method). The key person in Riau Province are smallholder representative (2 persons), middleman (2 persons), private oil palm plantation (1 persons), Biodiesel Company (2 persons), plasma cooperative (1 
person), and palm oil mill (1 persons). The key person in North Sumatera Province are smallholder representative ( 2 persons), palm oil mill (1 person), middleman ( 1 person), and biodiesel company (1 person). Besides, to strengthen policy analysis in this study, thus an in-depth interview to several policy maker was also employed i.e. Ministry of energy and mineral resource, Indonesia biodiesel association, and National energy council of Indonesia. Table 1 below enlighten data analysis used in this study.

Table 1. Research approaches and data analysis

\begin{tabular}{cccc}
\hline No & Objectives & Research Approach & Data Analysis \\
\hline 1 & To analyze the sustainability of palm oil & & $\bullet$ Survey (150 smallholders of each site) \\
based biodiesel & & $\begin{array}{c}\text { R Non-survey (in-depth interview with key } \\
\text { person in upstream-downstream sectors) }\end{array}$ & $\begin{array}{c}\text { Rappects of sustainability i.e. } \\
\text { economy, ecology, and social }\end{array}$ \\
\hline 2 & $\begin{array}{c}\text { To formulate policies need to resolve palm } \\
\text { oil-based biodiesel sustainability issues }\end{array}$ & $\begin{array}{c}\bullet \text { Non-survey (in-depth interview with key } \\
\text { person and policy maker) }\end{array}$ & Descriptive qualitative \\
\hline
\end{tabular}

To answer the aims of this research, a life cycle (upstreamdownstream) perspective was discussed using the rapbioenergy approach to determine the status of sustainability indices. Rap-bioenergy constitutes a modification of the rapfish (Rapid Appraisal for Fisheries) technique, which is based on the Multidimensional Scaling (MDS) approach. The rapfish approach was originally introduced to determine the sustainability status of fishery catches [41], as it was with its early use in Indonesia [42]. In MDS, two of the same points or objects were mapped with points close to each other. Conversely, objects or points that are not the same were indicated by points far apart. Ordination or distance determination techniques in MDS were based on Euclidian distance in n-space, and written as follows:

$$
d=\sqrt{\left(\left|x_{1}-x_{2}\right|^{2}+\left|y_{1}-y_{2}\right|^{2}+\left|z_{1}-z_{2}\right|^{2}+\cdots\right.}
$$

Configurations of objects or points in MDS were then approximated by regressing Euclidian distance (dij) from point $\mathrm{i}$ to point $\mathrm{j}$ with point of origin $\left(\mathrm{o}_{\mathrm{ij}}\right)$, as the following equation shows:

$$
d_{i j}=\alpha+\beta \delta_{i j}+\varepsilon
$$

The regression technique used for the equation above was the ALSCAL algorithm [42]. The ALSCAL method optimizes squared distance $($ squared distance $=$ dijk) against squared data (point of origin $=\mathrm{o}_{\mathrm{ijk}}$ ), which in three dimensions $(\mathrm{i}, \mathrm{j}, \mathrm{k})$ is written in a formula called S-Stress as follows:

$$
S=\sqrt{\frac{1}{m} \sum_{k=1}^{m}\left[\frac{\sum_{i} \sum_{j}\left(d_{i j k}^{2}-o_{i j k}^{2}\right)^{2}}{\sum_{i} \sum_{j} o_{i j k}^{4}}\right]}
$$

where, the squared distance is Euclidian distance assigned a value:

$$
d_{i j k}^{2}=\sum_{\alpha=1}^{r} w_{k \alpha}\left(x_{i \alpha}-x_{j a}\right)^{2}
$$

The Rap-bioenergy ordination analysis in the sustainability study for palm oil-based biodiesel in Indonesia comprised a number of stages: (1) determination of palm oil-based biodiesel sustainability attributes in Indonesia covering three (3) dimensions: ecological, economic, and social; (2) evaluation of each attribute on an ordinal scale (scoring) based on sustainability criteria for each dimension; (3) ordination analyses; and (4) preparation of sustainability indices and status for palm oil-based biodiesel.

MDS was used with rap-bioenergy methods in order to ascertain sustainability indices for palm oil-based biodiesel. Every attribute in each sustainability dimension was assigned a score based on scientific judgment from the scorer. Scores ranged from $0-10$, starting from bad (0) to good (10), or viceversa. Then, scores for each attribute were analysed multidimensionally to determine points reflecting sustainability positions for palm oil-based biodiesel, which were assessed against two reference points; good points and bad points. Sustainability index scales with intervals of $0-100$ percent, are detailed in Table 2.

Table 2. Index categories and biodiesel sustainability status using rap-bioenergy

\begin{tabular}{cc}
\hline Index value (percent) & Category \\
\hline $0.00-25.00$ & Bad (unsustainable) \\
$25.01-50.00$ & Lacking (relatively unsustainable) \\
$50.01-75.00$ & Reasonable (relatively sustainable) \\
$75.01-100.00$ & Good (sustainable) \\
\hline
\end{tabular}

\section{SUSTAINABILITY OF BIOENERGY PRODUCTION IN INDONESIA}

Energy is believed to be a main driver of the economy in the world, which determines success towards the application of the concept of sustainability and sustainable development. The energy sources used and the amount consumed have a significant influence on the environment, society and the economy in general. Access to green, adequate and affordable energy services will help the social welfare impacts of the population [43]. However, the increase in world crude oil prices and the adverse effects on the environment have implications for the increasing demand for biofuels including biodiesel, which is considered as one of the ways of sustainable energy production. However, in the development and implementation, would need the attention of all parties concerned with the sustainability dimensions covering the biodiesel industry.

Palm oil-based biodiesel industry development involves relationships between complex, interdependent elements that hold potential for substantial risks in their management. In part, the success of developing palm oil-based biodiesel is highly dependent on palm oil production as the raw material provider. Risks that have to be faced include weather, climate, pests and diseases, and how prices for palm oil as a raw material for biodiesel compete with those for palm oil as edible oil. These factors affect raw material supply in terms of volume, quality, and production continuity [44]. Nineteen sustainability variables/criteria were chosen and encompassed by three (3) 
sustainability of bioenergy planning aspect categories: economic, ecological, and social (see Table 3), and analyzed using MDS. The variables used referred to studies from Buchholz [40], GBEP and FAO [45], and Cramer et al. [46].

The biodiesel industry is a prospective palm oil downstream industry group in Indonesia. Domestically, palm oil-based biodiesel is functioning in meeting the target of the B30 biodiesel acceleration program in 2025 that supports the National energy mix policy. In addition, along with the increasing world attention to the issue of climate change, the export markets of Indonesian palm biodiesel products indirectly to various countries are also increasingly available. The use of biodiesel in various sectors has been proven to be able to reduce $\mathrm{CO}_{2}$ production into the environment. However, on the other hand there is still debate over environmental issues addressed to oil palm plantations which are currently the main source of biodiesel as a raw material. The European
Union and the United States are also aggressively stating the negative issues regarding palm oil-based biodiesel in Indonesia, thus harming the Indonesian palm oil market in these countries. Thus, sustainability issues must be a concern of all parties involved.

From the results of the MDS analyses, which covered the 19 variables above (as shown in Table 3), sustainability performance figures were obtained for biodiesel in Indonesia. In some aspects, degrees of sustainability were sufficient, but in others, showed worrying figures. Figure 2 presents these analysis results using rap-bioenergy techniques in the form of a kite diagram, which differentiates between the two research locations, i.e. Riau and North Sumatra provinces. In this research, six palm oil-based biodiesel value chain stakeholder types in Riau, and four in North Sumatra were evaluated in regard to sustainability.

Table 3. Variables affecting biodiesel sustainability in Indonesia, 2018

\begin{tabular}{ccc}
\hline Category & No & Sustainability Attributes \\
\hline & 1 & Product price (fresh fruit bunches and crude palm oil) \\
& 2 & Fresh fruit bunch production and productivity \\
Economic & 3 & Product demand (domestic and overseas) \\
& 4 & Production costs \\
& 5 & Subsidies/incentives (replanting and biodiesel) \\
& 6 & Supporting infrastructure \\
\hline & 1 & Nearby water sources \\
& 2 & Droughts and floods in oil palm plantation areas \\
Ecological & 3 & Biodiesel certification at the company and estate levels \\
& 4 & Changing land use, land illegality, and deforestation \\
& 5 & COn emissions (life cycle basis) \\
& 6 & Worest fires in oil palm areas \\
& 7 & Changes in earnings (smallholders and worker wages) \\
& 1 & Employment \\
Social & 2 & Work/business opportunities \\
& 3 & Use of child labor \\
& 4 & Conflicts (in oil palm estates, palm oil mills, and biodiesel plants) \\
& 5 & Health and education infrastructure \\
\hline
\end{tabular}

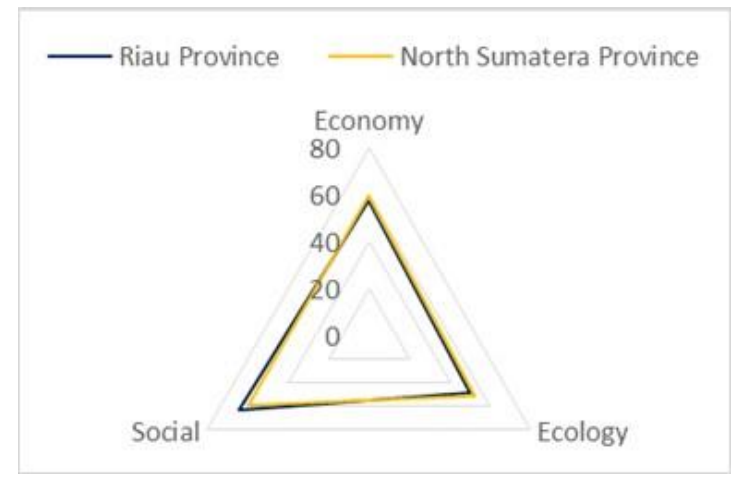

Figure 2. Palm oil-based biodiesel sustainability indices in Riau and North Sumatra Provinces, Indonesia

The results show that sustainability index for the ecological dimension of palm oil-based biodiesel in Riau to be the lowest of all indices, at relatively unsustainable, with an index score of 49.8 percent. Sustainability index analysis results for palm oil-based biodiesel in North Sumatra were different to those for Riau. The ecological sustainability index value was slightly higher for North Sumatra than for Riau, at 53.9 percent, which indicates relatively sustainable status. Sustainability index scores for the other five aspects in both provinces ranged from
50.01-75.00 percent, indicating relatively sustainable status. The lowest sustainability index score in North Sumatra was for institutional sustainability, at 50.7 percent, while in Riau this was the second lowest index value at 54.6 percent. Though the status of biodiesel sustainability studies at both locations are on the range of 49.8 and 53.9 and categorized as quite sustain, but in fact they are in a State that is worrying because of the low level of sustainability.

\subsection{Economic sustainability status}

The attributes that influence the sustainability of palm oil based biodiesel in Indonesia for economic dimensions are: (1) product prices, (2) production and productivity of product (such as FFB and CPO), (3) product demand, (4) production costs, (5) Subsidies/incentives, and (6) supporting infrastructure. The sustainability of the economic dimension is essential to recognize due to the sustainability of palm oilbased biodiesel is also depend on the economic aspects received by each party in the upstream and downstream production of palm oil-based biodiesel. Using rap-bioenergy, the status of economic aspect ordination for palm oil-based biodiesel in both Riau and North Sumatra had relatively sustainable. In Riau, the smallest economic sustainability 
index value was for smallholders at 50.4 percent. The same condition also applied in North Sumatra where smallholders had the smallest economic sustainability index value compared to other stakeholder, at 56.5 percent (Figure 3). However, economic sustainability indices for all stakeholder types, in both Riau and North Sumatra, ranged from 50.0175.00, which indicates relatively sustainable status.

Generally, in both locations the economic aspect status was relatively sustainable, though a variety of issues caused by several supporting factors are still associated with palm oilbased biodiesel. One of these is that despite there being traceability and quality issues with palm oil and derivative products, there is still a demand for uncertificated or low quality Fresh Fruit Bunches (FFBs) produced by oil palm smallholders. In other words, FFBs from uncertificated plantations can still be accepted by processing plants and become Crude Palm Oil (CPO). In downstream area, biodiesel producers can increase economic sustainability values despite losses resulting from working below optimum production capacity. Companies address this with a strategy of integrating biodiesel and cooking oil industries into one unitary operational unit. That way, losses in the biodiesel sector can be offset by profits from cooking oil industries. Therefore, the economic aspect for upstream and downstream biodiesel industries in both North Sumatra and Riau can be considered relatively sustainable, even though illegality on the upstream side remains a challenge.

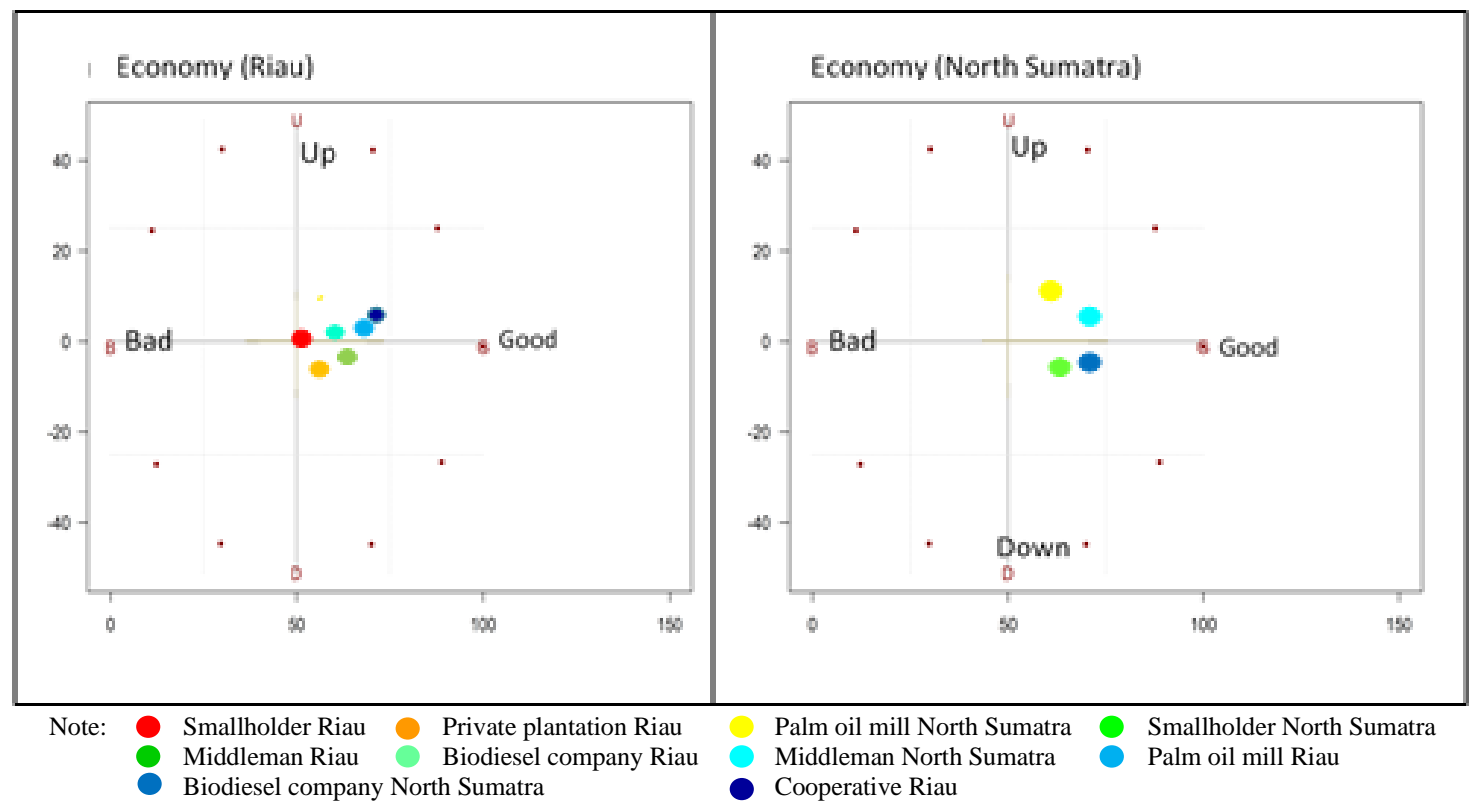

Figure 3. Economic sustainability ordination in Riau and North Sumatra provinces

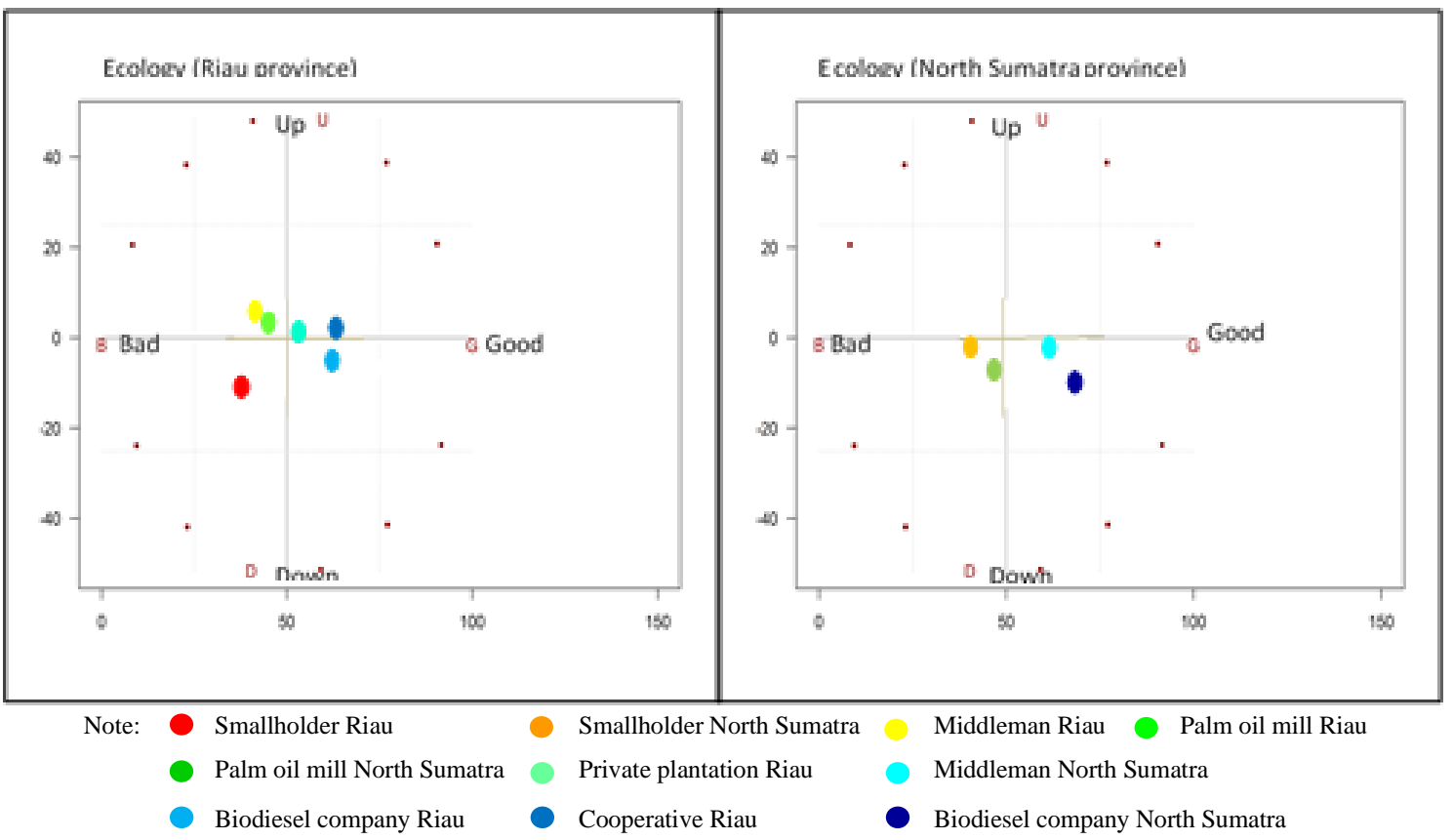

Figure 4. Ecological sustainability ordination in Riau and North Sumatra provinces 


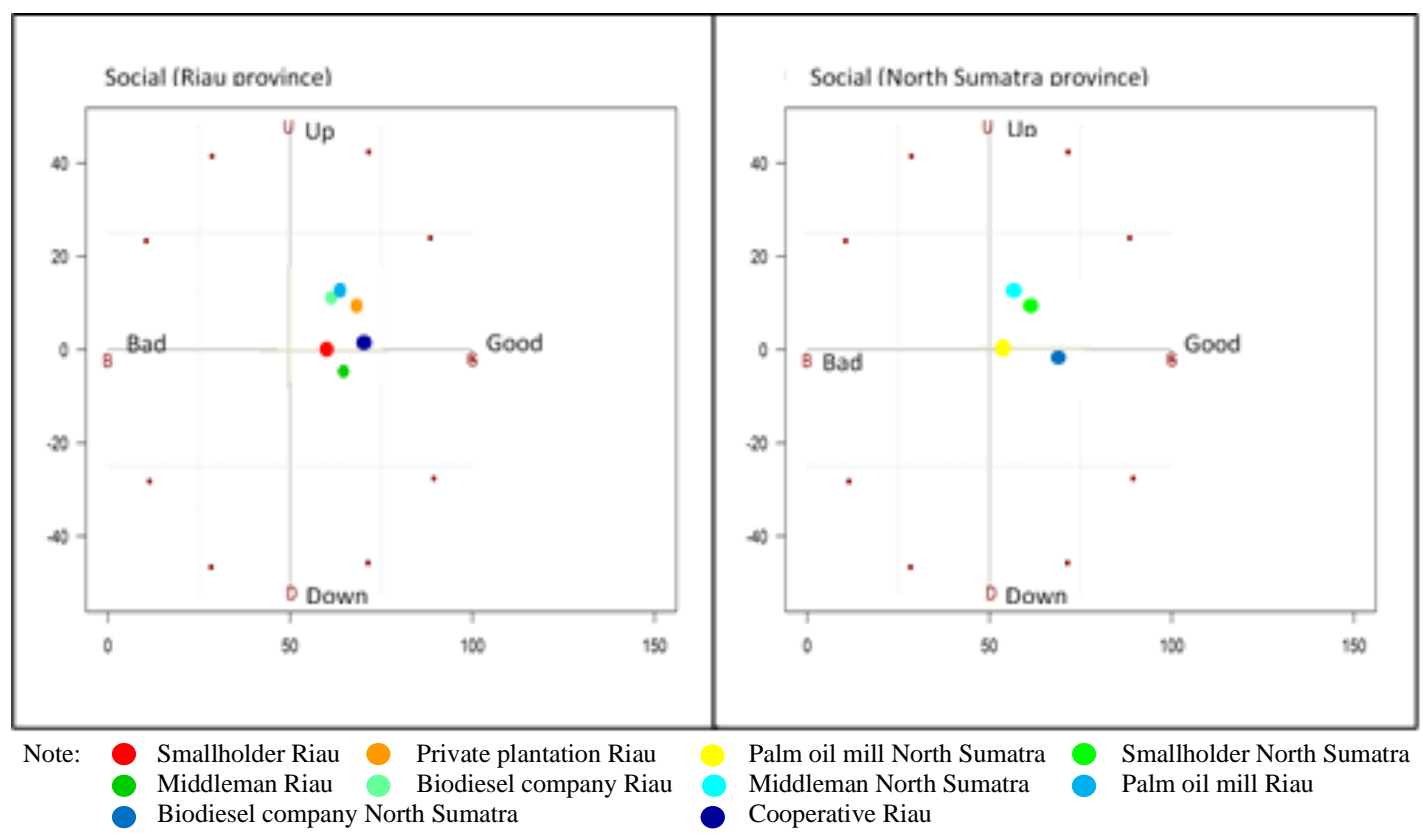

Figure 5. Social sustainability ordination in Riau and North Sumatra provinces

\subsection{Ecological sustainability status}

The most important downstream ecological aspect is the impact of biodiesel plant and CPO mill operations on the environment [47]. Attributes considered will influence the sustainability of ecological dimension, are: (1) quality of water resources, (2) land use, (3) fires potential, (4) the incidence of droughts and floods, (5) $\mathrm{CO}_{2}$ emissions (base on life cycle thinking), (6) certification, and (7) the availability of waste management.

In the upstream, the study reveals there are important environmental risks from CPO processing mills owned by large scale plantation companies, particularly from liquid waste threatening local ecosystems. Figure 4 shows upstream ecological unsustainability, particularly at the smallholders' plantation and CPO industry levels. At the smallholders' level, the unsustainability issue is very strongly marked by plantation tenure illegality and oil palm seedling illegality in most smallholders owned plantations.

The other issue of upstream ecological unsustainability is becoming increasingly serious, with the fact that some CPO industries pose prominent negative externality risks to the environment and to communities, which they are unable to overcome or internalize [48-50]. The attributes of land conversion and deforestation and biodiesel certification attributes are sensitive attributes in the ecological dimension of sustainability of palm oil-based biodiesel in Indonesia. This means that if these attributes are removed, the sustainability score of palm oil-based biodiesel from the ecological dimension will be disrupted. With the issues of land tenure illegality, liquid waste, and seedling illegality, the CPO produced from smallholders' plantation faced problems of low credibility on international market.

\subsection{Social sustainability status}

The social aspect shows how palm oil-based biodiesel industries, including the oil palm estates that supply them with raw materials, impact upon communities. The existence of plantations and palm oil-based biodiesel industries has a variety of impacts, both positive and negative, on social life
$[12,51]$. Several attributes that expected will influence the status of social dimension sustainability are: (1) the use of child labor, (2) employment, (3) business opportunities, (4) changes in people's income, (5) conflict, and (6) health and education infrastructure.

The social sustainability index value in Riau was 63.9 percent; higher than in North Sumatra at 59.2 percent. But generally, both of these index values show that palm oil-based biodiesel in Indonesia can in fact bring positive social impacts, such as community earnings increases and public infrastructure improvements (Figure 5).

The results show that upstream sectors, i.e. oil palm estates, have higher index values than downstream sectors. The presence of oil palm estates is more socially acceptable to communities as they benefit from direct involvement as independent or smallholder. Increases in FFB prices, which plummeted in 2015 , have been triggered by the development of palm oil-based biodiesel production in Indonesia. Further, these price increases have opened employment opportunities for communities and women. In oil palm plantations, female workers usually gather fallen FFBs and clear weeds around oil palms. This increase in employment opportunities in rural areas, including for women, is a positive aspect of oil palm estates in many regions in Indonesia and in other tropical regions $[52,53]$.

The existence of oil palm plantations is socially more beneficial to the community because they are directly involved as independent and plasma of oil palm plantation. The increase in FFB prices which had dropped dramatically in 2015, one of which was triggered by the development of palm oil-based biodiesel production in Indonesia. Furthermore, with the increase in prices, more opportunities for employment for the community and women have opened up. In oil palm plantations, female workers usually work as collectors of FFB that fall and clean the shipyards around oil palm trees. Increasing employment opportunities for women is also demonstrated by Balogun and Salami [53], who reviewed the impact of biofuel production for local communities in Nigeria. The results of empirical study on the two research sites, especially in Riau Province showed that only one social indicator for sustainability has been a very critical issue. Social 
conflict in those areas are obvious as far as some smallholders tried to encroach and to convert land belonging to National Park areas to become oil palm plantation. This became the most severe issues. Meanwhile, five other indicators showed positive results.

\section{POLICY ANALYSIS OF PALM OIL-BASED BIODIESEL SUSTAINABILITY}

The policy to transition from fossil to non-fossil energy by using palm oil is facing complex and complicated issues in its implementation. In the context of developing palm oil-based biodiesel in Indonesia, high-quality governance is also considered to determine its sustainability, including setting up strict regulation [54]. Government guarantees regarding sustainability in the upstream palm oil-based biodiesel sector need to be a priority. The fact that oil palm plantations should be able to improve the economy of the community and regional economic growth, must be accompanied by serious efforts to ensure the successful reduction of the negative impacts of oil palm plantations on social and environmental aspects significantly. On one hand the Government wants to reduce carbon emissions and guarantee clean energy development in accordance with Law No. 30/2007 on Energy.

On the other hand, the policy has far-reaching consequences with the ever wider use of vegetable materials, particularly palm oil. Demand for palm oil has increased sharply as a result of biodiesel energy growth. The response upstream has been massive and uncontrolled expansion of oil palm estates bringing about negative excess returns to the ecological sustainability of forest ecosystems. Oil palm estate expansion leads to occupation of conservation and forestry estates, which results in an inability in FFB production to account for traceability and sustainability. In other words, biodiesel production in Indonesia is facing natural resource and sustainability issues because it lacks on guarantee the legality or origin of the land or seedlings for the palm oil raw materials it uses, nor ecosystem sustainability.

Table 4. Policy analysis based on rap-bioenergy assessment in two research sites, 2018

\begin{tabular}{|c|c|c|c|c|}
\hline \multirow{2}{*}{$\begin{array}{c}\text { Research } \\
\text { sites }\end{array}$} & \multicolumn{3}{|c|}{ Sustainability Index (\%) } & \multirow{2}{*}{$\begin{array}{c}\text { Policy } \\
\text { Implications }\end{array}$} \\
\hline & Social & Ecology & Economic & \\
\hline $\begin{array}{c}\text { Riau } \\
\text { Province }\end{array}$ & 57.56 & 49.80 & 63.93 & $\begin{array}{l}\text { a. Strengthening } \\
\text { ecological } \\
\text { sustainability, } \\
\text { particularly for } \\
\text { upstream }\end{array}$ \\
\hline $\begin{array}{c}\text { North } \\
\text { Sumatera } \\
\text { Province }\end{array}$ & 59.74 & 52.45 & 59.26 & $\begin{array}{c}\text { sector i.e. } \\
\text { smallholders } \\
\text { b. Gap analysis } \\
\text { on ISPO } \\
\text { implementation } \\
\text { c. Environmental } \\
\text { improvement } \\
\text { on CPO } \\
\text { processing by } \\
\text { CPO mills and } \\
\text { plantation } \\
\text { practices by } \\
\text { smallholders }\end{array}$ \\
\hline
\end{tabular}

As a result, its biodiesel supply chains are neither accountable, nor credible. The implication is that biodiesel products from Indonesia are assessed poorly in international markets. Policy analysis related to palm oil based biodiesel sustainability is gathered from rap-bioenergy analysis for sustainability assessment in two research sites in Indonesia (Table 4).

The Government's target to achieve biodiesel production levels in accordance with Government Regulation (PP) No. $79 / 2014$ on the National Energy Strategy, i.e. 23\% of total energy production by 2025 increasing to $31 \%$ by 2050 , is facing serious challenges regarding biodiesel's sustainability, credibility and market acceptance in international markets. At the root of all these issues are unaccountable FFB raw material production processes at the smallholder oil palm estate and CPO industry levels, and biodiesel still having several negative externality impacts.

Certification becomes an essential instrument in a framework of ensuring responsible traceability, and accountable ecological sustainability [55]. Certification systems use Roundtable on Sustainable Palm Oil (RSPO) and Indonesian Sustainable Palm Oil (ISPO) schemes in accordance with Minister of Agriculture Regulation No. 11/Permentan/OT.140/3/2015. The Indonesian government through the Ministry of Agriculture launched the Indonesian Sustainable Palm Oil (ISPO) Guidelines, which aim to ensure the implementation of legislation related to oil palm plantations so that sustainable palm oil can be produced and support the commitment of the President of the Republic of Indonesia to reduce greenhouse gases. Unlike the RSPO which is voluntary, as a regulation of the Indonesian government, the ISPO is mandatory for plantation companies but voluntary for smallholders. This regulation was renewed in March 2015 to become the Indonesian Sustainable Palm Oil Certification System [56].

The implementation of the ISPO certification system applies to plantation companies that carry out plantation cultivation business integrated with CPO processing businesses, plantation companies that do business in plantation cultivation only, and smallholders. ISPO requires that oil palm plantation companies that will submit ISPO certification must first go through the Plantation Business Assessment (PUP) stage carried out by the local Plantation Service (Province / Regency) with the classification of plantations must include classes I, II or III. Whereas for smallholdings and independent smallholdings businesses are not subject to plantation classification regulations (Ministry of Agriculture, ISPO, and UNDP, 2015). This procedure is considered very complicated especially for smallholders, causing that many of them are not capable to implement ISPO very perfectly. As results, only few smallholders are able to certify their plantation to be ISPO certified.

Furthermore, at the level of biodiesel producers, there are also certifications that can support the sustainability of palm oil-based biodiesel in Indonesia, especially for international market targets, namely the certification of International Sustainability and Carbon Certification (ISCC). ISCC is a certification system for environmental sustainability and prevention of greenhouse gas emissions. In July 2011, the European Union commission recognized ISCC as the first certification scheme capable of demonstrating compliance with EU requirements "Renewable Energy Directive's (RED)". The ISCC certification can be applied to meet the requirements of the bioenergy market share in an effort to demonstrate 
sustainability [57].

The study reveals some important points to mention. These are: (1) there are a complexity of the energy transition policy in Indonesia where oil palm is a resources that is not easily used due to the absence of strong market domestically as well as internationally; 2. Achieving the target of energy transition is also hard to realize due to ecological problem associated mostly with the oil palm operation of smallholders; 3 . ISPO Certification is an effort to streamline the transition energy process in Indonesia, but in fact it is still difficult to be implemented particularly for smallholders, due to complexity of procedures and requirements; and 4. problems of bad governance in ecological aspect that is mainly encountered by smallholders.

\section{CONCLUSION AND POLICY IMPLICATION}

Palm oil-based biodiesel production in Indonesia in a framework of transition from fossil to non-fossil fuel energy is also facing sustainability dilemmas, particularly in regard to upstream ecological sustainability from all biodiesel value chains. The ecological unsustainability issue is particularly apparent in smallholders' oil palm plantations and CPO industries belonging to big companies. In economic and social terms, this study in two biodiesel industry centres concludes that biodiesel industry growth affords favourable social and economic impacts in expanding employment opportunities for local communities, including women. However, some social conflicts have been a critical issue in terms of social and economic sustainability.

Implications of the policy to transition from fossil to nonfossil energy supposed to be focus on biodiesel industry growth and massive oil palm estate expansion. Developments in biodiesel energy such as palm oil-based biodiesel provide fresh optimism to the clean energy discourse because they can reduce carbon and greenhouse gas emissions. However, palm oil-based biodiesel development carries serious risks of oil palm estate expansion into forestry and conservation areas, which threatens ecosystem sustainability. To control oil palm estate expansion that has an impact on which threatening ecosystem sustainability, a good agricultural production governance must be applied.

In future, certification instruments like the Roundtable on Sustainable Palm Oil (RSPO) and Indonesian Sustainable Palm Oil (ISPO) should be applied bindingly and fully to biodiesel supply chains from upstream to downstream. If sustainability needs to be achieved, the certification implementation policy should make certification mandatory rather than voluntary to all oil palm economic actors, i.e. large scale plantation estate, large scale plantation estate with mill processing industries, and smallholders.

\section{ACKNOWLEDGMENT}

The authors would like to thank to the research project on the topic of Forests in the global bioeconomy: Developing multi-scale policy scenarios that is jointly conducted between Center for Agricultural and Rural Development Studies of Bogor Agricultural University (CARDS-IPB) and Center for International Forestry Research (CIFOR). This study is made possible by the financial support from the Federal Ministry of Economic Cooperation and Development (Germany).

\section{REFERENCES}

[1] Williams, C.L., Dahiya, A., Porter P. (2015). Introduction to Bioenergy. Bioenergy: Biomass to Biofuels. Elsevier Ltd, London, UK, 5-36. https://doi.org/10.1016/B978-0-12-407909-0.00001-8

[2] Sheng, Y., Shi, X., Zhang, D. (2014). Economic growth, regional disparities and energy demand in China. Journal of Energy Policy, 71(C): 31-39. https://doi.org/10.1016/j.enpol.2014.04.001

[3] Waramit, N. (2012). Developing a bioeconomy in Thailand. Journal of ISSAAS, 18(2): 34-44.

[4] Demirbas, A., Demirbas, I. (2007). Importance of rural bioenergy for developing countries. Journal of Energy Conversion and Management, 48(8): 2386-2398. https://doi.org/10.1016/j.enconman.2007.03.005

[5] Toman, M., Jemelkova, B. (2003). Energy and economic development: An assessment of the state of knowledge. Energy Journal, 24(4): 93-112.

[6] Speirs, J., McGlade, C., Slad, R. (2015). Uncertainty in the availability of natural resources: Fossil fuels, critical metals and biomass. Journal of Energy Policy, 87(C): 654-664. https://doi.org/10.1016/j.enpol.2015.02.031

[7] Scarlat, N., Dallemand, J.F., Ferrario, F.M., Nita, V. (2015). The role of biomass and bioenergy in a future bioeconomy: Policies and facts. Journal of Environmental Development, 15: 3-34. http://dx.doi.org/10.1016/j.envdev.2015.03.006

[8] Timmons, D., Harris, J.M., Roach, B. (2014). The economics of renewable energy. A GDAE teaching module on social and environmental issues in economics. Global Development and Environment Institute Tufts University.

[9] Masjuki, H.H., Kalam, M.A., Mofijur, M., Shahabuddin M. (2013). Biofuel: Policy, standardization and recommendation for sustainable future energy supply. Energy Procedia, 42: 577-586. https://doi.org/10.1016/j.egypro.2013.11.059

[10] World Energy Council. World Energy Resources; Bioenergy 2016.2016 https://www.worldenergy.org/wpcontent/uploads/2017/ 03/WEResources_Bioenergy_2016.pdf.

[11] Popp, J., Lakner, Z., Harangi-Rákos, M., Fári, M. (2014). The effect of bioenergy expansion: Food, energy, and environment. Journal of Renewable and Sustainable Energy Reviews, 32: 559-578. https://doi.org/10.1016/j.rser.2014.01.056

[12] Demirbas, A. (2017). The social, economic, and environmental importance of biofuels in the future. Journal Energy Sources, Part B: Economics, Planning, and Policy, 12(1): 47-55. https://doi.org/10.1080/15567249.2014.966926

[13] Thondhlana, G. (2014). The local livelihood implications of biofuel development and land acquisitions in Zimbabwe. Africa Initiative and the Centre for International Governance Innovation (CIGI).

[14] Tomei, J. (2014). Global policy and local outcomes: A political ecology of biofuels in Guatemala. $\mathrm{PhD}$ Thesis. University College London (UCL) - The Human Dimensions of Energy.

[15] Mol, A.P.J. (2007). Boundless biofuels? Between environmental sustainability and vulnerability. Sociologia Ruralis, 47(4): 297-314. https://doi.org/10.1111/j.1467-9523.2007.00446.x 
[16] [BPS] Indonesian Central Statistics Agency. (2016). Statistika Kelapa Sawit Indonesia (Indonesia Oil Palm Statistics) 2015. Badan Pusat Statistik. Jakarta.

[17] [APROBI] Association of Indonesian Biodiesel Companies. (2018). Keunggulan Biodiesel berbasis Kelapa Sawit. Seminar of RPOI. Bogor 24 April 2018.

[18] Schwaiger, H., Pena, N., Mayer, A., Bird D.N. (2011). Technologies to produce liquid biofuels for transportation: An overview. Working Paper 72. CIFOR, Bogor, Indonesia. https://doi.org/10.17528/cifor/003510

[19] Butler, R.A. (2010). Brazil launches major push for sustainable palm oil in the Amazon. MONGABAY, New \& Inspiration from Nature's Frontline. http://news.mongabay.com/2010/0507amazon_palm_oil.html.

[20] Gui, M.M., Lee, K.T., Bhatia, S. (2008). Feasibility of edible oil versus non-edible oil versus waste edible oil as biodiesel feedstock. Journal of Energy, 33(11): 16461653. https://doi.org/10.1016/j.energy.2008.06.002

[21] Damuri, Y.R., Atje, R. (2012). Investment Incentives for Renewable Energy: Case study of Indonesia. The International Institute for Sustainable Development.

[22] Robledo-Abad, C., Althaus, H.J., Berndes, G., Bolwig, S., Corbera, E., Creutzig, F., Garcia-Ulloa, J., Geddes, A., Gregg, J.S., Haberl, H., Hanger, S., Harper, R.J., Hunsberger, C., Larsen, R.K., Lauk, C., Leitner, S., Lilliestam, J., Lotze-Campen, H., Muys, B., Nordborg, M., Ölund, M., Orlowsky, B., Popp, A., Portugal-Pereira, J., Reinhard, J., Scheiffle, L., Smith, P. (2017). Bioenergy production and sustainable development: science base for policymaking remains limited. Journal of Global Change Biology-Bioenergy, 9(3): 541-556. https://doi.org/10.1111/gcbb.12338

[23] Stefanescu-Mihaila, R.O. (2016). Rural economy and bioethanol production. Journal of Sustainability, 8(11): 1148. https://doi.org/10.3390/su8111148

[24] Gunarso, P., Hartoyo, M.E., Agus, F., Killeen, T.J. (2013). Oil palm and land use change in Indonesia, Malaysia and Papua New Guinea. Reports from the Technical Panels of the 2nd Greenhouse Gas Working Group of the Roundtable on Sustainable Palm Oil (RSPO).

[25] Hunsberger, C., Bolwig, S., Corbera, E., Creutzig, F. (2013). Livelihood impacts of biofuel crop production: Implications for governance. Journal of Geoforum, 54: 248-260. https://doi.org/10.1016/j.geoforum.2013.09.022

[26] Gibbs, H.K. (2008). Carbon payback times for cropbased biofuel expansion in the tropics: The effects of changing yield and technology. Environmental Research Letters, 3: 034001. https://doi.org/10.1088/17489326/3/3/034001

[27] Cockerill, S., Martin, C. (2008). Are biofuels sustainable? The EU perspective. Biotechnology for Biofuels, 1(9). https://doi.org/10.1186/1754-6834-1-9

[28] Krzyśko-Łupicka, T., Cybulska, K., Wieczore, A., Możdżer, E., Nowak, M.J. (2014). The effect of spent bleaching earth ageing process on its physicochemical and microbial composition and its potential use as a source of fatty acids and triterpenes. Environmental Science and Pollution Research, 21(18): 10765-10774. https://doi.org/10.1007/s11356-014-3021-6

[29] Krisyanti, S., Sukandar. (2011). Recovery minyak dari limbah bahan berbahaya dan beracun (b3) spent bleaching earth dengan metode ekstraksi pelarut. Jurnal Teknik Lingkungan, 17(1): 35-46. http://dx.doi.org/10.5614\%2Fjtl.2011.17.1.4

[30] Petrenko, C., Paltseva, J., Searle, S. (2016). Ecological impacts of palm oil expansion in Indonesia. International Council on Clean Transportation (ICCT), Washington, pp. 1-15.

[31] Obidzinski, K., Andriani, R., Komarudin, H., Andrianto, A. (2012). Environmental and social impacts of oil palm plantations and their implications for biofuel production in Indonesia. Ecology and Society, 17(1): 25. http://dx.doi.org/10.5751/ES-04775-170125

[32] Lee, J.S.H., Abood, S., Ghazoul, J., Obidzinski, K., Koh, L.P. (2014). Oil palm smallholder yields and incomes constrained by harvesting practices and type of smallholder management in Indonesia. Agronomy for Sustainable Development, 34: 501-513. http://doi.org/10.1007/s13593-013-0159-4

[33] Rist, L., Feintrenie, L., Levang, P. (2010). The livelihood impacts of oil palm: Smallholders in Indonesia. Journal of Biodiversity Conservation, 19: 1009-1024. http://doi.org/10.1007/s10531-010-9815-z

[34] Tjakrawan, P. (2015). Competitiveness issues on palm oil biodiesel. The 3rd Bioenergy Week 2015, GBEP, Medan, Indonesia.

[35] Ofori-Boateng, C., Lee, K.T. (2013). The potential of using cocoa pod husks as green solid base catalysts for the transesterification of soybean oil into biodiesel: Effects of biodiesel on engine performance. Chemical Engineering Journal, 220: 395-401. http://dx.doi.org/10.1016/j.cej.2013.01.046

[36] Majore, G., Zakis, V., Zake, M., Ginters, E., Zakis, K., Fjodorovs, A. (2015). Holistic benchmarking of the bioeconomy in protected landscape areas. Journal of Procedia Computer Science, 43: 118-126. http://doi.org/10.1016/j.procs.2014.12.016

[37] Prandecki, K. (2014). Theoretical aspects of sustainable energy. Journal of Energy and Environmental Engineering, 2(4): 83-90. doi:10.13189/eee.2014.020401

[38] [Ditjenbun] Directorate General of Plantation. (2016). Statistik Perkebunan Indonesia 2014-2016. Jakarta. https://bps.go.id.

[39] Directorate General of New Energy, Renewable and Energy Conservation. (2016). Kebijakan Mandatori Biodiesel. Focus Group Discussion (FGD) Kajian Pemanfaatan Biodiesel. Kementerian Energi dan Sumber Daya Mineral Republik Indonesia.

[40] Buchholz, T., Luzadis, V.A., Timothy, A.V. (2009). Sustainability criteria for bioenergy systems: Results from an expert survey. Journal of Cleaner Production, 17: S86-S98. https://doi.org/10.1016/j.jclepro.2009.04.015

[41] Pitcher, T.J., Preikshot, D.B. (2001). Rapfish: A rapid appraisal technique to evaluate the sustainability status of fisheries. Fisheries Research, 49(3): 255-270. https://doi.org/10.1016/S0165-7836(00)00205-8

[42] Fauzi, A., Anna, S. (2005). Pemodelan Sumber Daya Perikanan dan Kelautan. Jakarta: PT. Gramedia Pustaka Utama.

[43] [IAEA] International Atomic Energy Agency. (2015). How the IAEA Will Contribute to the Sustainable Development Goals?

[44] Sastrosayono. (2006). Budidaya Kelapa Sawit. Agromedia Pustaka Jakarta. 
[45] [GBEP] Global Bioenergy Partnership and [FAO] Food \& Agriculture Organization. (2011). The Global Bioenergy Partnership Sustainability Indicators for Bioenergy.

http://www.globalbioenergy.org/fileadmin/user_upload/ gbep/docs/Indicators/The_GBEP_Sustainability_Indicat ors_for_Bioenergy_FINAL.pdf.

[46] Cramer, J., Hamelinck, C., Heuvel, E., Bergsma, G., Junginger, M., Smeets, E., Faaij, A. (2006). Criteria for Sustainable Biomass Production. Final report of the Project group 'Sustainable production of biomass'. http://www.globalproblems-globalsolutions-

files.org/unf_website/PDF/criteria_sustainable_biomass _prod.pdf.

[47] Teoh, C.H. (2011). Key Sustainability Issues in the Palm Oil Sector: A Discussion Paper for Multi-Stakeholders Consultations (commissioned by the World Bank Group). http://www.aph.gov.au/DocumentStore.ashx?id=0e9895 63-6299-48ad-af40-8604f73a494b

[48] Ngadi, N., Noveria, M. (2017). Keberlanjutan Perkebunan Kelapa Sawit di Indonesia dan Prospek Pengembangan di Kawasan Perbatasan. Jurnal Masyarakat Indonesia, 43(1).

[49] Jordan, R. (2014). Oil palm plantations threaten water quality, Stanford scientists say. Stanford Report. https://news.stanford.edu/news/2014/june/palm-oilwater-062614.html, accessed on June 30, 2014.

[50] Lord, S., Clay, J. (2014). Environmental impacts of oil palm - practical considerations in defining sustainability for impacts on the air, land and water. International Planters Conference on Higher Productivity and Efficient Practices for Sustainable Agriculture, The Incorporated Society of Planters. Putrajaya, Malaysia. http://www.nbpol.com.pg/wp-

content/uploads/downloads/2011/02/EnvironmentalImp actOfOilPalm.pdf.

[51] Hidayah, N., Dharmawan, A.H., Barus, B. (2016). The expansion of palm oil plantation and changes of rural social ecology. Jurnal Sosiologi Pedesaan Sodality, 4(3). https://doi.org/10.22500/sodality.v4i3.14434

[52] Azzahra, F., Dharmawan, A.H., Pandjaitan, N.K. (2017). Women and livelihood of household: analysis of oil palm expansion impact in Jambi. Jurnal Sosiologi Pedesaan Sodality, https://doi.org/10.22500/sodality.v5i1.16269

[53] Balogun, B.O., Salami, A.T. (2016). Effects of biofuel production on selected local communities in Nigeria. Journal of Petroleum Technology and Alternative Fuels, 7(3): 18-30. https://doi.org/10.5897/JPTAF2015.0123

[54] Lu, Y. (2020). An empirical analysis on the nonlinear relationship between economic growth and carbon dioxide emissions in China. International Journal of Sustainable Development and Planning, 15(2): 201-209. https://doi.org/10.18280/ijsdp.150210

[55] [UNECE] United Nations Economic Commission for Europe. (2015). Traceability of Agricultural Produce. UNECE Conference, 3 November 2015 Palais des Nations, Room VII, Geneva, Switzerland.

[56] Ministry of Agriculture, ISPO, \& UNDP. (2015). Studi bersama persamaan dan perbedaan sistem sertifikasi ISPO dan RSPO. https://rspo.org/articles/download/e002338a5f874f1

[57] [CIT-system] Citra Inti Training System. (2018). ISSC, International Sustainability \& Carbon Certification. https://www.tuv.com/world/en/iscc-internationalsustainability-and-carbon-certification.html. 